Review

\title{
Challenges for Plant Breeders from the View of Animal Nutrition
}

\section{Gerhard Flachowsky and Ulrich Meyer*}

Institute of Animal Nutrition, Friedrich-Loeffler-Institute (FLI), Federal Research Institute for Animal Health, Bundesallee 50, Braunschweig 38116, Germany; E-Mail: gerhard.flachowsky@ @li.bund.de

* Author to whom correspondence should be addressed; E-Mail: ulrich.meyer@ fli.bund.de; Tel.: +49-531-58044-137; Fax: +49-531-58044-299.

Academic Editor: Wayne L. Bryden

Received: 14 May 2015 / Accepted: 3 December 2015 / Published: 12 December 2015

\begin{abstract}
The question of how to feed the growing world population is very old, but because of the increase of population and possible climate change, currently it has an explosive impact. Plant breeding can be considered as the starting point for the whole human food chain. Therefore, high, stable and highly digestible yields of phytogenic biomass with low external inputs of non-renewable resources, such as water, fuel, arable land, fertilizers, etc.; low emissions of gases with greenhouse potential during cultivation; and high resistance against biotic and abiotic stressors, including adaptation to potential climate change, and a low concentration of undesirable substances in the plants are real challenges for plant breeders in the future. Virtually unlimited resources such as sunlight, nitrogen and carbon dioxide from the air as well as the genetic pool of microbes, plants and animals can be used to breed/develop optimal plants/crops. Biofortification of plants may also be an objective of plants breeders, but it is more important for human nutrition to avoid micronutrient deficiencies. A lower concentration of undesirable substances in the plants can be considered as more important than higher concentrations of micronutrients in plants/feeds. Animal nutritionists have various possibilities for feed additive supplementation to meet animal nutrient requirements. Examples to reduce undesirable substances in feed plants are discussed and shown in the paper. In summary, plant breeding has a large and strategic potential for global feed and food security. All breeding technologies may contribute to solving important global challenges, such as sustainable use of limited global resources, improved use of unlimited resources, adaption to climate change and lowering global greenhouse gas emission. More publically supported research seems to be necessary
\end{abstract}


in this field. All methods of plant breeding that contribute to a more resource-efficient production of high and stable yields of available biomass should be used/combined.

Keywords: plant breeding; animal protein; feeds; co-products; feed additives; biofortification; anti-nutritional factors

\section{Introduction}

Feed accounts for $50 \%$ to $70 \%$ of the cost of production of animal protein (i.e., meat, milk and eggs). Feeds can be defined as edible material(s) that are consumed by animals and deliver energy and/or nutrients such as protein/amino acids, fatty acids, minerals, vitamins, etc. to the animals' diet. On the other hand, feed plants may also contain undesirable substances, such as glucosinolates, mycotoxins, phytates, phytoestrogens, lignin, etc. Furthermore, feed production consumes high amounts of limited natural resources such as water, land area, fuel, fertilizers, etc. Therefore, feed efficiency or feed conversion (amount of feed per product of animal origin such as milk, eggs, meat or fish) is a potential parameter to assess feed utilization in animal nutrition [1,2].

Plant breeding can be considered as the starting point of the food chain all over the world [3-8], as shown in the simple food chain model in Figure 1. Traditional breeding, as well as "green" biotechnology or green chemistry [9], may result in changing of composition and nutritive value of feed plants.

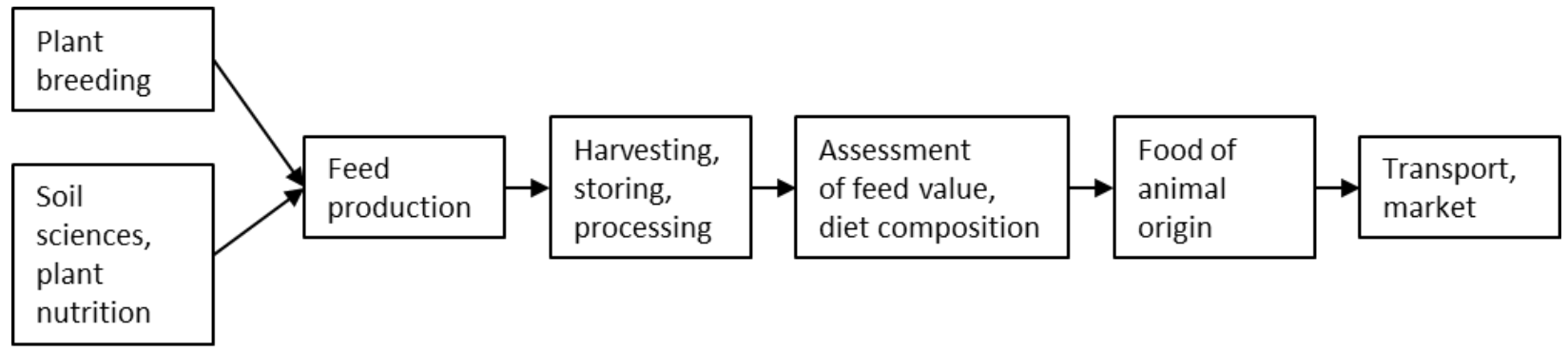

Figure 1. Plant breeding, feed production and feed science as key elements of the production of food of animal origin in the human food chain.

The present situation will continue with a steadily growing population, severe land and water constraints, an increase in demands for food and biofuel as well as with progressing climate change [10-12]. The objective of the present paper is to analyze challenges for plant breeding under special consideration of high and stable yields, efficient use of limited resources and reduction of the content of undesirable ingredients in feed plants.

\section{Global Food Situation and Challenges}

According to the FAO (Food and Agriculture Organization of the United Nations) [13,14], the human population will increase globally from currently about seven billion to more than nine billion 
people in 2050, but the increase in the output of food of animal origin is estimated to be about $70 \%$ above the current production $[15,16]$.

More people and a higher need for feed and food are associated with a growing demand for limited natural resources such as water, fuel, minerals, arable land, etc., and elevated emissions with greenhouse gas $(\mathrm{GHG})$ potential such as carbon dioxide $\left(\mathrm{CO}_{2}\right)$, methane $\left(\mathrm{CH}_{4}\right)$, nitrous oxide $\left(\mathrm{N}_{2} \mathrm{O}\right)$ and other substances (e.g., N, P, trace elements, etc.). These changes characterize the situation all over the world [2,5,9,13,14,17-24]. Malnutrition in all its forms (undernutrition, micronutrient deficiencies (e.g., iron, iodine, vitamin A) and overnutrition - the so-called "triple burden" of malnutrition) is still recognized as a serious and intractable problem for human beings [25,26]. The latest FAO estimates [27] indicate that about 805 million people are still chronically undernourished (11.3\% of global population). Food of animal nutrition, also called animal source food [28], may contribute to overcoming micronutrient deficiencies [26].

\subsection{Food of Animal Origin}

The energy and protein conversion efficiency from feed into food of animal origin is low and may vary between $3 \%$ (energy-beef) up to $40 \%$ (energy-dairy; protein-chicken) for fattening [29,30]. In some countries (e.g., USA), between $67 \%$ (energy) and $80 \%$ (protein) of the crops are used as animal feed [29].

These developments and complex connections present the following question: "Is there any need for food of animal origin?" As vegans demonstrate, there is no essential need for food of animal origin, if the human diets are supplemented with all essential nutrients. However, on the other hand, the consumption of meat, fish, milk and eggs may contribute significantly to meeting the human requirements for amino acids [26,31-35] and some important trace nutrients (such as $\mathrm{Ca}, \mathrm{P}, \mathrm{Zn}, \mathrm{Fe}, \mathrm{I}$, Se, and Vitamins A, D, E, and B12), especially for children and juveniles, as well as for pregnant and lactating women [36]. Human nutritionists [37,38] have recommended that about one-third of the daily protein requirements $(0.66-1 \mathrm{~g}$ per $\mathrm{kg}$ body weight) [34,37,39-42] of adults should originate from protein of animal origin. Consequently, about $20 \mathrm{~g}$ of the daily intake of about $60 \mathrm{~g}$ protein should be of animal origin, which is lower than the present average consumption throughout the world. Presently, there is an average consumption of protein of animal origin (without fish) of about $24 \mathrm{~g}$ per capita per day, ranging between 1.7 (Burundi) and $69.0 \mathrm{~g}$ (USA; Table 1). It is a challenge for the future to overcome this imbalance [33]. Meat, milk and eggs provide around $13 \%$ of the energy and $28 \%$ of protein consumed globally, respectively, with the higher share in the so-called developed countries (around 20\% and 40\%, respectively [14]). It is difficult to assess the protein intake from fish and other animal protein sources (e.g., insects). Avadi and Freon [43] estimate that half of the world's population consumed at least $15 \%$ of their animal protein from aquaculture. Protein from insects may contribute to improving the protein intake of human and animals in many developing countries [44].

Other reasons for consumption of food of animal origin are the high bioavailability of most nutrients and their considerable "enjoyment value". Such food is also presently considered as an indicator for the standard of living in many regions of the world. Eating food of animal origin, especially meat, is not only a reflection of nutritional needs, but it is also determined by organoleptic, as well as by geographical area, culture, ethics and wealth. Further reasons for the higher demand of food of animal origin in some countries are the increased income of the population [25,45-47] and the imitation of the 
so-called "Western lifestyle" concerning nutritional habits. Many developing countries continue to consume more animal products than they produce. Therefore, they will continue to drive the world demand for all agricultural products, including food of animal origin [48]. Higher food amounts of animal origin require higher plant yields and/or more area for feed production [49-51] and more animals and/or higher animal yields as well an increase in agricultural trade. Therefore, some authors propose a redefinition of agricultural yield and agriculture in general: "from tons to people nourished per hectare" [29,45] and ask for more sustainable animal agriculture [52-54].

Table 1. Intake of milk, meat and eggs as well as protein of animal origin per capita per year and portion $(\%)$ of total protein intake (global minimum-values; maximum-values and averages as well as German values for comparison; $\mathrm{kg}$ per capita per year: data base $2005 ;[14]$.

\begin{tabular}{lcccc}
\hline Food & Minimum & Average & Maximum & Germany \\
\hline Milk (kg per year) & 1.3 (Congo) & 82.1 & 367.7 (Sweden) & 248.7 \\
Meat $^{1}$ (kg per year) & 3.1 (Bangladesh) & 41.2 & 142.5 (Luxembourg) & 83.3 \\
Eggs (kg per year) & 0.1 (Congo) & 9.0 & 20.2 (China) & 11.8 \\
Edible protein of animal origin (g per capita and day) & 1.7 (Burundi) & 23.9 & 69.0 (USA) & 52.8 \\
Portion of animal protein in \% of total protein intake per capita & 4.0 (Burundi) & 27.9 & 59.5 (USA) & 53.7 \\
\hline
\end{tabular}

${ }^{1}$ Probably empty body weight (meat plus bones).

On the other hand, changing the eating patterns [55] and eating less or no livestock products, especially meat, are often seen as possible solutions to reduce the environmental impact of animal agriculture [56-58] and to reduce the per capita land requirements $[59,60]$. In this context, it should be mentioned that the use of permanent pastures, which represent a significant proportion of the agricultural area for the production of food, is only possible with food-producing animals.

\subsection{Limited Resources and Low Emissions}

In the future, there will be strong competition for arable land and further non-renewable resources such as fossil carbon-sources, water [61-64], some minerals (such as phosphorus; [65,66]), as well as between feed, food, fuel, fiber, flowers and fun (6 F-concept) [67] and areas for settlements and natural protected areas.

In this regard, more attention should be paid to the need of limited natural resources per amount of animal product, expressed as footprints per product such as "Water Footprints", [68,69] "Mineral (especially phosphorus; P) Footprints", "Land (arable or total land) Footprints" [59,70-72]. These Footprints are given in $\mathrm{kg}$; $\mathrm{L}$ or tons per unit of product and characterize the efficiency of various production processes.

On the other hand, special attention has also been paid to the outputs from agriculture [19,23] including livestock keeping especially so-called $\mathrm{GHG}$ relevant emissions such as $\mathrm{CO}_{2}, \mathrm{CH}_{4}, \mathrm{~N}_{2} \mathrm{O}$ and further gases. All the climate relevant emissions are summarized to so-called Carbon Footprints (CF). They have also been modified or called Ecological Footprint (EF), Eco-Balances (EB), Life Cycle Assessments (LCA) or Life Cycle Impact Assessment (LCIA). In all cases the term means a summarized parameter for all gaseous emissions with greenhouse gas potential to sensitize producers 
and consumers $[73,74]$ to an efficient use of fossil carbon sources and to reduce GHG emissions per product [75]. CF or LCA are used as a tool for estimating environmental effects caused by products or processes. Furthermore, CF may also contribute to assessing the resource and feed efficiency between various regions and production systems [49].

\subsection{Social Aspects}

In addition to these limited natural conditions, there is also a social side to the present situation. Based on developments mentioned above, social and natural scientists of various disciplines have increasingly studied and analyzed these global developments. The balance between the Planet (global resources and emissions), People (social aspects of population all over the world) and Profit (economic aspects, money-making) in the so-called 3P-concept [76,77] is an important prerequisite for a sustainable life and development on the Earth. Some authors are afraid that the balance between the 3Ps being increasingly disturbed and that an ethical dimension should be introduced as a fourth dimension $[1,77,78]$.

Profit should not and cannot be the single objective of production. We need to find a balance between a careful and sustainable use of limited resources (see section 2.2) on the one hand [79-81] and low emissions with local and global consequences for later generations [82] on the other hand. Progress in plant breeding to more efficient plants in using natural resources and plants with high and stable yields which contribute to stabilizing human nutrition with food of plant and animal origin can be a starting to overcome imbalances in the $3 \mathrm{P}$-concept.

\subsection{Challenges for Plant Breeders}

A rising demand for animal feed due to increasing consumption of food of animal origin is expected to drive the market for many feed crops such as maize, soybean, rapeseed, sugarcane, sugar beet and forages. Further alternatives to stabilize and improve human and animal nutrition, such as insects [1,83-87], microbial biomasses [88,89], food imitates, etc., are under discussion.

More studies and analyses seem to be necessary to improve the data basis for a more efficient use of limited resources and lower emissions per product. Therefore, in addition to a previous review [90] the objective of the present contribution is to analyze the challenges for plant breeders to meet the expectations of animal nutritionists to feed food-producing animals adequate to their requirements and under consideration of future human demand. The term "plant breeding" is used for all methods to improve the potential of plants, independent of traditional methods or green biotechnologies.

\section{Feeds and Animal Requirements}

\subsection{Feeds}

Feeds are characterized according to their composition as summarized in Table 2. Water for drinking is not considered as an own group of feeds, but it is an essential prerequisite for animal health and welfare. The most important feed groups are roughages, concentrates and co-products from agriculture, food and biofuel industry [91]. Feeds from these groups contain various amounts of crude nutrients, but also traces of further essential and non-essential substances. 
More details on feeds, feed evaluation and feed value tables may be found in various textbooks and publications such as Becker and Nehring [92], Menke and Huss [93], Kling and Woehlbier [94], Jeroch et al. [95], Jeroch et al. [96], Jeroch et al. [97], Theodorou and France [98]; Ewing [99], Ewing [100], and Kamphues et al. [101].

In some countries (e.g., in Germany), so-called "Positiv list's" for straight feeding stuffs exist [102] where parameters of using as feedstuffs are summarized. This "Positive list" is not a legal document, but it should be considered as a voluntary commitment of the feed industry to produce high quality mixed feed.

Feed additives are used to supplement feed (mixed or complete feed) with essential and/or non-essential substances (see Figure 2). Further details on the effects of various feed additives in animals, food of animal origin and on the environment are described in some reviews [103-105], in many publications, in opinions papers of the European Food Safety Authority (EFSA), and other national and international scientific bodies.

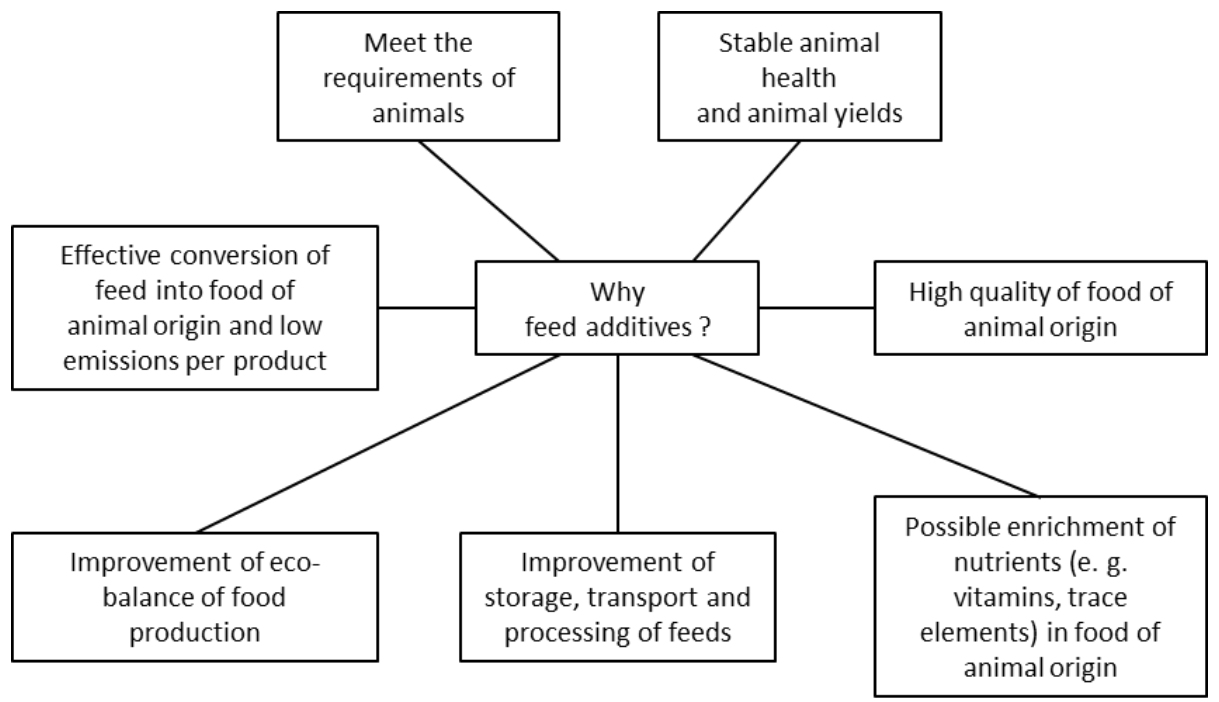

Figure 2. Reasons for the use of feed additives in animal nutrition.

Table 2. Systematic of feed groups.

\begin{tabular}{ll}
\hline Feed Group & \multicolumn{1}{c}{ Characterization } \\
\hline \multirow{2}{*}{ Water for drinking } & $\begin{array}{l}\text { Essential in adequate amounts (2-5 L per kg feed dry matter (DM); average: about 3 L/kg } \\
\text { DM) for animal health, efficient feed conversion and quality of food of animal origin }\end{array}$ \\
\hline \multirow{2}{*}{ Roughage } & $\begin{array}{l}\text { Vegetative plant parts (leaves, stalks) of grasses and legumes fed in fresh (forages), conserved } \\
\text { (silages) or dried form (hay, straw). Roughages contain B-glycosidic bound carbohydrates } \\
\text { mainly as cellulose and hemicelluloses associated with lignin. Cell wall fractions are } \\
\text { dominating in roughages. }\end{array}$ \\
\hline \multirow{3}{*}{ Concentrate } & $\begin{array}{l}\text { Generative plant parts (seeds) of cereals, legumes and oilseeds, roots, tubers and other feeds } \\
\text { rich in } \alpha \text {-glycosidic bound carbohydrates (starch, etc.). Concentrates are also rich in cell } \\
\text { content-containing proteins and fats. }\end{array}$ \\
\hline \multirow{2}{*}{ By-/Co-products } & $\begin{array}{l}\text { Co-products are residues of agriculture (e.g., straw), food (e.g., bran, beat pulp, bagasse) and } \\
\text { biofuel industry (such as distillers grain solubles, oil cake or extracted oil meal, glycerine, etc.) }\end{array}$ \\
\hline \multirow{2}{*}{ Feed additives } & $\begin{array}{l}\text { Essential (such as amino acids, minerals, vitamins) and non-essential substances (e.g., } \\
\text { enzymes, microorganisms) which are added to feed in small amounts }\end{array}$ \\
\hline
\end{tabular}




\subsection{Animal Requirements}

Requirements for energy and essential nutrients of food producing animals and laboratory animals are given in feeding standards. For example, in the United States, Latin America and many other regions of the world, the recommendations of the National Research Council (NRC; since 1945) of the National Academy of Sciences provide the basis for the formulation of the diets in livestock feeding. In the UK and many Commonwealth countries, recommendations were given by the Agricultural Research Council (ARC), since 1983 called the Agricultural and Food Research Council (ARFC). Since 1994, the Biotechnology and Biological Science Research Council (BBSRC), as the successor organization to the ARFC, has stopped publishing the energy and nutrient requirements for farm animals. In France the INRA (Institute National de la Recherche Agronomique) and in Australia the CSIRO (Commonwealth Scientific and Industrial Research Organisation), as Australia's national science agency, issue appropriate recommendations. In Germany, recommendations for the supply of energy and nutrients to different farm animals are given by the Society of Nutrition Physiology (Gesellschaft für Ernährungsphysiologie; GfE).

Because of rapidly expanding knowledge in feed science and animal nutrition, nutritional standards are under continuous review and modification. New scientific results are used in the revision of adequate standards. During the last few years, recommendations of the NRC dominated and data by other organizations, except the GfE, were more or less neglected, or other organizations stopped their activities in the field of animal nutrition. Irrespective of the guidelines and recommendations from scientific societies, the legislation on animal feed of different countries includes provisions concerning the quality of feedstuffs.

\section{Challenges for Plant Breeding}

\subsection{General Challenges}

As already mentioned, plant breeding and cultivation will be the key elements and starting points for feed and food chain (see Figure 1) and for feed and food security in the future as well $[4,5,7,12,20,106,107]$.

Such crops should have high and stable yields, they should grow with the least possible use of globally limited resources such as arable land, water, fuel, and some minerals and they should ensure the best use of the unlimited resources such as plant nutrients in the atmosphere, sun energy and the available genetic pool (Table 3).

Table 3. Potential to produce phytogenic biomass and its availability per inhabitant under consideration of the increase of the population [108].

\begin{tabular}{cc}
\hline Plant Nutrients in the Atmosphere $\left(\mathbf{N}_{2}, \mathbf{C O}_{2}\right)$ & $\uparrow \leftrightarrow$ \\
\hline Solar energy & $\leftrightarrow$ \\
Agricultural area & $\downarrow$ \\
Water & $\downarrow$ \\
Fossil Energy & $\downarrow$ \\
Mineral plant nutrients & $\downarrow$ \\
Variation of genetic pool & $\uparrow$ \\
$(\uparrow$ Increase, $\downarrow$ Decrease, $\leftrightarrow$ no important influence $)$ & \\
\hline
\end{tabular}


Pennisi [106] characterized the ideal crop or the perfect plant from the perspective of plant breeders with the following parameters:

1. Improve the nutrient content of seeds and edible plant parts

2. Asexual reproduction

3. Optical warning signal or installation of warning lights

4. Higher water efficiency

5. Longer shelf life (enhanced control of ripening and senescence)

6. Improve nitrogen efficiency

7. Better pest resistance

8. Plants for mitigating adverse climatic changes and adverse environmental conditions

Adaptation of plants to the expected climate change is also a real challenge to plant breeders. Presently, special attention is given to the adaptation of plants to expected climate changes [11,109-112] and to improving their yield and the nutritive value for global food security [10]. The expected climate change may be considered as a substantial challenge for plant breeding in general.

Projections of global climate changes expect the concentration of greenhouse gases to increase, temperature fluctuations to occur sharply and frequently, and spatial and temporal distribution of rainfall to be disturbed [110]. All these influencing factors will increase challenges to crops.

In addition to plants with high and stable yields, we need plants that are

- resilient to such adverse environmental conditions,

- $\quad$ able to introduce such changes fast and sustainably, and

- $\quad$ available for all farmers (including smallholders [6]).

More attention should also be spent in further development of local varieties to improve the feed and food security of smallholder farmers. Presently, a small number of food and feed crops are cultivated worldwide (e.g., maize, rice, wheat, soybean, and sugar beet). From the view of sustainability, plants should be further improved by plant breeders.

Furthermore, it might be advantageous to support plant breeding by public institutions to a greater extent and to carry out more scientific work in this area with public research institutions.

\subsection{Special Challenges from the View of Animal Nutrition}

\subsubsection{Specific Challenges for Feed Plants}

Most of the general expectations mentioned before are also important for plants for animal feeding. Under consideration of the present challenges, an ideal feed crop can be characterized by the following goals:

- High and stable yields of highly digestible biomass with low external inputs (low input varieties) of non-renewable external resources such as water, minerals, fossil fuel, plant protection agents, etc. (see Table 3).

- Maximal/efficient use of naturally unlimited resources such as solar energy, nitrogen and carbon dioxide in the air (see Table 3).

- Higher resistance against abiotic and biotic stressors.

- Stable plant health and adaptation to potential climate change. 
- Low concentrations of anti-nutritive (toxic) substances such as secondary plant ingredients, mycotoxins from toxin-producing fungi, toxins from anthropogenic activities or geogenic origin such as heavy metals.

- Low concentrations of substances that influence the use or bioavailability of nutrients such as lignin, phytate, enzyme inhibitors, tannins, etc.

- Higher concentrations of some secondary plant products with "positive" properties for some purposes, such as carotinoids, essential oils, some polyphenols (e.g., flavonoids and anthocyanids) and even alkaloids, if the synthesis in plants is more effective than the industrial production.

A higher concentration of nutritive value-determining components such as amino acids, minerals, vitamins and vitamin precursors, enzymes, pro- and prebiotics, essential oils and other substances is also mentioned as an objective of plant breeding [113]. Of course, the plant breeding goals depend also from the climate conditions of region or continent, the animals kept in the region and the level of productivity of animals.

\subsubsection{Increase of Valuable/Desirable Substances}

Apart from water and energy, humans and animals require many nutrients to meet their metabolic need (essential nutrients). Table 4 reviews such nutrients known to be essential for sustaining human and animal life.

In some cases, plants enriched with adequate nutrients could be more sustainable for human, but also for animal nutrition. A large number of newly bred plants (crops and vegetables) of the so-called "second generation" (plants with output traits or with substantial changes in composition) with specific benefits for the consumer and animals are being developed or are in development [113]. These plants with increased nutritional content are also called biofortified plants or crops [114-117]. They can have a great impact on improving the already existing food and feed supply [118].

Table 4. Grouping and essential nutrients for humans and animals.

\begin{tabular}{|c|c|}
\hline Groups of Nutrients & Examples of Essential Nutrients \\
\hline Amino acids & $\begin{array}{l}\text { Histidine, Isoleucine, Leucine, Lysine }{ }^{1} \text {, Methionine, Phenylalanine, Threonine, } \\
\text { Tryptophan, Valine (semi-essential: Arginine, Cystine) }\end{array}$ \\
\hline Fatty acids & Linoleic acid, Linolenic acid \\
\hline Major elements & Calcium, Magnesium, Phosphorus, Sodium, Potassium, Sulfur, Chloride \\
\hline $\begin{array}{l}\text { Trace elements } \\
\text { Ultra trace elements }{ }^{2}\end{array}$ & $\begin{array}{l}\text { Iron, Zinc, Copper, Manganese, Iodine, Selenium, Cobalt (cobalamin; vitamin } B_{12} \text { ) } \\
\text { Fluorine, Boron, Molybdenum, Nickel, Chromium, Vanadium, Silicon, Arsenic, } \\
\text { Cadmium, Lead, Lithium, Tin }\end{array}$ \\
\hline $\begin{array}{l}\text { Vitamins (fat soluble) } \\
\text { (water soluble) }\end{array}$ & $\begin{array}{l}\text { A (retinol, precursor B-carotene), D }\left(\mathrm{D}_{2} \text { Ergocalciferol, } \mathrm{D}_{3} \text { Cholecalciferol, }\right. \\
\mathbf{E} \text { (Tocopherol), } \mathrm{K} \text { ( } \mathrm{K}_{1} \text { Phylloquinone, } \mathrm{K}_{2} \text { Menaquinone, } \mathrm{K}_{3} \text { Menadione) } \\
\mathrm{B}_{1} \text { (thiamin), } \mathrm{B}_{2} \text { (riboflavin), } \mathrm{B}_{6} \text { (pyridoxin), } \mathbf{B}_{12} \text { (cobalamin), Pantothenic acid, Niacin, } \\
\text { Folate, Biotin, } \mathrm{C} \text { (ascorbic acid) }\end{array}$ \\
\hline
\end{tabular}

A similar situation can be observed in smallholder farms. Their farming is characterized by various limitations, such as bad management of natural resources, most home production, limited marketing 
and other restrictions [6]. Feed additives to supplement animal diets are mainly not available. Modern plant breeding may be also attractive to smallholders. They could do some changes faster and could cut breeding time. Using new varieties of plants resistant to diseases or pests may prevent the spread of plant diseases within and between fields and thereby could protect and enhance smallholder assets.

Specific advantages are higher content(s) of important nutrients and substances with nutritional values, such as (mentioned with some references): protein and/or amino acids [121-123], fat or specific fatty acids [124-126], starch or special carbohydrates [122], specific minerals [117,127-131], vitamins or vitamin precursors [132-136], and enzymes [137-140]; or lower contents in undesirable substances such as: glucosinolates [141], gluten [142], mycotoxins [143,144], and phytate.

It has also to be considered that not only the quantity of these ingredients has to be provided, but the balance may also be important. This is of particular significance for small holders.

A similar structure is used by Hirschi [115] to characterize biofortified crops for human nutrition. The author distinguished between protein and amino acids, carbohydrates, micronutrients and functional metabolites on the one hand, and on plant components with suggested functionality such as dietary fiber, carotenoids, fatty acids, flavonoids, glucosinolates, phenolics, plant sterols, phytoestrogens, sulfides and tannins on the other hand $[145,146]$.

\subsubsection{Biofortification of Feed by Plant Breeding or Feed Additives?}

Food from biofortified crops can reach rural populations including smallholder farmers for reducing levels of micronutrient malnutrition as discussed and demonstrated by many authors during the last few years [114,117,147-155].

Many feed additives, such as amino acids, minerals, enzymes, and microorganisms are available for animals [103] and present EU feed law. Inadequate consumption of one of these nutrients will result in metabolic disturbances leading to lower feed intake, weaker performance of animals and lower feed efficiency, but also to sickness, poor health, impaired development of juveniles and higher costs for humans and animals [26,130,152]. Therefore, nutritional supplementation of diets is common for humans and animals to avoid deficit situations.

Such additives are mostly cheaper and their development and production is mostly faster than via plant breeding. In contrast to human nutrition, a higher concentration of the nutritive value determining components such as nutrient precursors, nutrients, enzymes, prebiotics, essential oils, etc., should not be a prior plant breeding objective from the view of animal nutrition (see Table 5).

Table 5. Pros and cons of substantial changes in plant composition (Plants of the second generation; plants with output traits or biofortified plants).

\begin{tabular}{l|l}
\hline \multicolumn{1}{c|}{ Pro } & \multicolumn{1}{c}{ Contra } \\
\hline More advantages for human nutrition (meet requirements, e.g., fatty acids, & Plant breeding needs a long time (longer than the \\
minerals, vitamins, etc.) than for animal nutrition (except smallholders or & development of food/feed additives) \\
farmers far from transport ways) & Many feed additives are available for animal \\
Lower content of undesirable substances & nutrition \\
Improvement of properties of food/feed & \\
\hline
\end{tabular}

Plant breeding can also be used to produce plants richer in oils, starch, fiber, protein or other substances useful for food/feed and industrial processes [153]. Generally, such substances are mainly 
extracted from the crops and so-called co-products (e.g., soybean meal, rapeseed meal, and cotton seed meal; see [91]) could be available for animal nutrition. Except for the extracted nutrient(s), co-products do not vary strongly from their isogenic counterparts in the composition of main nutrients [156,157], but analyses are necessary for the composition of such co-products.

Biofortified plants may contribute to reducing micronutrient under-nutrition in many parts of the world. Presently, nutritionally improved plants have not been fully developed [158] and tested for their potential to improve the micronutrient status of humans and animals. Many biofortified plants are still in the pipeline and must be tested in animal feeding studies in the next years. More in vitro studies and animal experiments are necessary to assess the bioavailability of micronutrients in biofortified plants and to demonstrate the effects of further desirable ingredients such as enzymes [113]. Furthermore, there is a need for better communication between plant breeders and human and animal nutritionists about the potentials of plant breeding for future improvements in nutrition and health.

\subsubsection{Reduction of Content of Undesired (Anti-Nutritive) Compounds}

It is easy to supplement some feed additives to animal diets, but it is difficult and expensive to remove undesired substances from the feed [159]. Therefore, a great challenge for plant breeders is to reduce the content of undesired components in feed plants. The following could be some goals for plant breeders:

- lower concentrations of substances that influence the use or the bioavailability of nutrients, such as phytate, tannin, enzyme inhibitors, lignin, and silicon;

- lower concentrations of toxic substances (secondary plant substances), such as alkaloids, glucosinolates, phenolic compounds, phytoestrogens, and cyanic compounds;

- $\quad$ higher resistance against fungi, such as Fusarium, Aspergillus, Penicilium, ergot, etc.; and

- minimal residues resulting from human/agricultural practices or soil composition, such as plant protection substances, soil composition, etc.

Brown midrib (bm) hybrids (e.g., corn and sorghum) demonstrate the influence on digestibility [160-163] and rumen fermentation, feed intake and the performance of ruminants [161,164-167] as a result of traditional mutation breeding [168-171]. Lower fiber content and higher digestibility of plants may reduce methane emission from the rumen [172]. On the other hand, Schwarm et al. [173] found no effect on methane emissions of German Holstein heifers fed corn silage from a brown midrib mutation compared with control maize. One wish to plant breeders could be to select cereal varieties with low lignin/fiber content in the stalk, but a high standing stability of plants.

Based on these data, plant breeding may also be helpful to increase feed value and feed intake of low quality roughages and co-products. During harvesting of plants, such as cereals, legumes, sugar beets, sugar cane, etc., co-products such as straw, beet leaves and sugar cane are potential feed, especially for ruminants because of the high fiber content [174-177]. The digestibility and, therefore, also the feed value of such co-products, is higher the lower the lignin/fiber content. Therefore, lignin is also considered to be an undesirable constituent of feed. Lignin and fiber fractions (e.g., NDF, ADF, 
crude fiber) are very important for the digestibility and the feed value of vegetative parts of plants as well as the performance of ruminants.

In conclusion, from the view of animal nutrition reduction of the content of undesirable substances from feed plants via plant breeding seems to be more important than biofortification. It is extremely difficult and expensive to remove or destroy undesirable substances in feed [159], but large amounts of feed additives are available to supplement feeds/diets with essential and non-essential feed additives [103].

\subsubsection{Testing of Results of Plant Breeding in Animal Nutrition}

The evaluation of results of plant breeding measures from the perspective of animal nutrition requires a range of measures. Nutritional/physiological evaluation should be included in addition to composition determination. Such studies can take place in the laboratory (in vitro) or with laboratory and target animals (in vivo). Various types of animal feeding studies, such as measuring digestibility/bioavailability; efficiency studies including the transfer of nutrients from feed into food of animal origin as well as long-term and multi-generational feeding studies with feeds resulting from plant breeding have been described by many organisations [178-183] and were recently summarized by Flachowsky [3] and Van Eenennaam and Young [184].

Studies with target animal species are necessary to evaluate the nutritional value and safety of changes induced in the plant. Animal nutrition can be considered as the connection between plant and animal breeding. The cooperation between plant breeders and animal nutritionists should start in early breeding stages to analyze effects of breeding on the nutritive value of the "new" feed. Such feeding studies are the fundamentals for animal experimentation with new results of plant breeding.

Various types of in vitro and animal feeding studies are necessary to demonstrate the effects of results of plant breeding in food producing animals, such as:

- $\quad$ in vitro studies,

- $\quad$ studies with animal models to determine the bioavailability,

- $\quad$ efficacy trials with target animals, and

- $\quad$ in addition, safety trials should be considered.

King [151] proposed a three-step process for the nutritional assessment of food from biofortified plants of in human nutrition:

- Test of the bioavailability of newly expressed or nutrient(s) expressed in higher amounts.

- Feeding trial(s) to test the efficacy of the biofortified food for improving the nutrition and health of the target population.

- Final trial for evaluating the nutritional, health, agricultural, societal, environmental and economic aspects of biofortified food in the community.

Similar steps seem to be necessary in animal nutrition. Experimental designs are discussed for such studies and are described in detail by Flachowsky and Böhme [185], Flachowsky et al. [186], ILSI [182], EFSA [179], and Llorente et al. [187].

Table 6 demonstrates the effects of low phytate maize (reduced content of the undesirable substance phytate) on animal performance, phosphorus excretion and bone stability in a feeding study with pigs. 
The "new" low phytate maize showed the same results as maize with more phytate and supplemented with 2 or $1.5 \mathrm{~g}$ inorganic phosphorus/kg feed, but a significantly lower P excretion, increased P-efficiency and environmental advantages (Table 6).

Table 6. Conventional and low-phytate maize (78.5\% of the mixture) in the feed of fattening pigs (from [188,189]).

\begin{tabular}{|c|c|c|c|c|}
\hline \multirow{3}{*}{$\begin{array}{l}\text { Groups } \\
\text { Parameters } \\
\text { Inorganic P supplement }\end{array}$} & \multicolumn{2}{|c|}{ Control } & \multicolumn{2}{|c|}{ Low-Phytate Maize } \\
\hline & \multicolumn{2}{|c|}{ ( $0.3 \mathrm{~g}$ of available $P$ per $\mathrm{kg})$} & \multicolumn{2}{|c|}{ (1.7 $\mathrm{g}$ of available $P$ per $\mathrm{kg})$} \\
\hline & not added & added & not added & added \\
\hline \multicolumn{5}{|l|}{$P$ content $(\mathrm{g} / \mathrm{kg})$} \\
\hline 29-73 kg live weight & 3.4 & $5.4^{1}$ & 3.4 & $5.4^{1}$ \\
\hline $73-112 \mathrm{~kg}$ live weight & 3.2 & $4.7^{2}$ & 3.2 & $4.7^{2}$ \\
\hline Feed intake (kg/day) & $2.23^{\mathrm{a}}$ & $2.50^{\mathrm{b}}$ & $2.53^{\mathrm{b}}$ & $2.51^{\mathrm{b}}$ \\
\hline Live weight gain (g/day) & 730 & $870^{b}$ & $900^{b}$ & $880^{b}$ \\
\hline Feed per gain (kg/kg) & $3.05^{\mathrm{a}}$ & $2.87^{b}$ & $2.81^{\mathrm{b}}$ & $2.85^{b}$ \\
\hline P excreted (g/kg weight gain) & $4.6^{\mathrm{a}}$ & $8.9^{\mathrm{c}}$ & $3.8^{b}$ & $8.8^{\mathrm{c}}$ \\
\hline Strength (4th metacarpal bone, kg) & $79.3^{\mathrm{a}}$ & $138.5^{\mathrm{b}, \mathrm{c}}$ & $132.2^{b}$ & $153.9^{\mathrm{c}}$ \\
\hline Ash content (\% in 4 th metacarpal bone) & $53.5^{\mathrm{a}}$ & $60.1^{\mathrm{b}, \mathrm{c}}$ & $59.3^{\mathrm{b}}$ & $61.2^{\mathrm{c}}$ \\
\hline
\end{tabular}

\section{Conclusions}

More people and a higher need for feed and food are associated with a growing demand for limited natural resources such as water, fuel, minerals, arable land, etc., as well as elevated emissions with greenhouse gas potential.

Plant breeding can be considered as the starting point of the food chain. High, stable and highly digestible yields of plants with low external inputs of non-renewable resources, low emissions of gases with greenhouse potential during cultivation, high resistance against biotic and abiotic stressors including adaptation to potential climate change, and a low concentration of undesirable substances in the plants are real challenges for plant breeders in the future and are important for human and animal nutrition.

Additional challenges for plant breeders from the view of animal nutrition are:

- $\quad$ considering of forages and grassland by plant breeders;

- biofortification of plants is not so important for animal nutritionists because of many feed additives available in a large number of countries;

- feed value of co-products should be considered after processing of "new" plants for food and biofuel;

- animal feeding studies with target animal species are recommended to evaluate the nutritional value and safety of the changes induced in the plants; and

- cooperation between plant breeders and animal nutritionists should be an early element of breeding programs.

More attention should be paid to a more efficient use of non-renewable resources and the maximal use of unlimited resources (see Table 3). 
Plant breeding with conventional breeding methodologies and/or genetic engineering has the potential, or can at least contribute, to overcome many problems of malnutrition. Furthermore, more education is necessary to inform the masses about the benefits/advantages of modern plant breeding for global food security.

It can be concluded that plant breeding is the starting point for a successful food chain under the title "more (feed and food) for more (people) with less (resources and emissions)".

More activities are necessary for the sustainable utilization of natural limited resources and for improved use of unlimited resources such as sun energy/light, $\mathrm{CO}_{2}$ and $\mathrm{N}_{2}$ from the air, the global gene pool, etc. Conventional plant breeding may also contribute to fulfilling some of these objectives, but genetic modification may be faster and more precise [12]. More public supported research in this field seems to be necessary. All methods of plant breeding that contribute to a more resource-efficient production of high and stable yields of available biomass should be used/combined. Public funding of plant and animal research may be considered as an important challenge to meet the future animal protein demand [2].

\section{Author Contributions}

This paper was written by Gerhard Flachowsky and Ulrich Meyer.

\section{Conflicts of Interest}

The authors declare no conflicts of interest.

\section{References}

1. Makkar, H.P.S.; Ankers, P. Towards sustainable animal diets: A survey-based study. Anim. Feed Sci. Technol. 2014, 198, 309-322.

2. National Research Council. Critical Role of Animal Science Research in Food Security and Sustainability; National Academic Press: Washington, DC, USA, 2015; p. 360.

3. Flachowsky, G. Animal Nutrition with Transgenic Plants; Flachowsky, G., Ed.; CABI: Wallingford, UK, 2013.

4. Flachowsky, G.; Meyer, U.; Grün, M. Plant and animal breeding as starting points for sustainable agriculture. In Sustainable Agriculture Reviews; Lichtfouse, E., Ed.; Springer Netherlands: Berlin, Germany, 2013; pp. 201-224.

5. Harvie, A. Food Security: Challenges, Role of Biotechnologies and Implications for Developing Countries; Nova Science Publisher: Hauppauge, New York, NY, USA, 2015; p. 250.

6. Ruane, J.; Dargie, J.D.; Mba, C.; Boettcher, P.; Makkar, H.P.S.; Bartley, D.M.; Sonnino, A. Biotechnologies at Work for Smallholders: Case Studies from Developing Countries in Crops, Livestock and Fish; FAO: Rome, Italy, 2013.

7. The Royal Society. Reaping the Benefits: Science and the Sustainable Intensification of Global Agriculture; The Royal Society: London, UK, 2009. 
8. Flachowsky, G.; Wenk, C. The role of animal feeding trials for the nutritional and safety assessment of feeds from genetically modified plants-Present stage and future challenges. J. Anim. Feed Sci. 2010, 19, 149-170.

9. Guillou, M.; Matheron, G. The World's Challenge-Feeding 9 Billion People; Springer Netherlands: Berlin, Germany, 2014; p. 226.

10. Fischer, T.; Byerlee, D.; Edmeades, G. Crop Yields and Global Food Security: Will Yield Increase Continue to Feed the World; ACIAR: Canberra, Australia, 2014.

11. Reynolds, M.P. Climate Change and Crop Production; CAB International: Wallingford, UK; Cambridge, MA, USA, 2010.

12. Tester, M.; Langridge, P. Breeding technologies to increase crop production in a changing world. Science 2010, 327, 818-822.

13. Food and Agriculture Organization of the United Nations. The State of Food and Agriculture 2009: Livestock in the Balance; FAO: Rome, Italy, 2009; p. 166.

14. Food and Agriculture Organization of the United Nations. How to Feed the World in 2050; FAO: Rome, Italy, 2009; p. 35.

15. Alexandratos, N.; Bruinsma, J. World Agriculture towards 2030/2050; FAO: Rome, Italy, 2012.

16. HLPE. Biofuels and Food Security (vo Draft); FAO: Rome, Italy, 2013.

17. Ash, C.; Jasny, B.R.; Malakoff, D.A.; Sugden, A.M. Feeding the future. Science 2010, 327, 797-797.

18. Delgado, C.L. Rising consumption of meat and milk in developing countries has created a new food revolution. J. Nutr. 2003, 133, 3907S-3910S.

19. Food and Agriculture Organization of the United Nations. Livestock's Long Shadow: Environmental Issues and Options; FAO: Rome, Italy, 2006; p. 406.

20. Godfray, H.C.; Beddington, J.R.; Crute, I.R.; Haddad, L.; Lawrence, D.; Muir, J.F.; Pretty, J.; Robinson, S.; Thomas, S.M.; Toulmin, C. Food security: The challenge of feeding 9 billion people. Science 2010, 327, 812-818.

21. IPCC. (Intergovernmental Panel on Climate Change). Guidelines for National Greenhouse Gas Inventories; Agriculture, Forestry and Other Land Use. Available online: http://www. ipce-nggip.iges.or.jp/public/2006/gl/vol4.html (accessed on 12 May 2015).

22. Steinfeld, H.; Gerber, P.; Wassenaar, T.; Castel, V.; Rosales, M.; Haan, C.D.; de Haan, C. Livestock's Long Shadow: Environmental Issues and Options; FAO: Rome, Italy, 2006.

23. Vermeulen, S.J.; Campbell, B.M.; Ingram, J.S.I. Climate change and food systems. Annu. Rev. Environ. Resour. 2012, 37, 195-222.

24. Flachowsky, G. More for more with less? Mühle Mischfutter 2014, 151, 34-38. (In German)

25. HLPE. Note on Critical and Emerging Issues for Food Security and Nutrition; FAO: Rome, Italy, 2014.

26. Thompson, B.; Amoroso, L. Improving Diets and Nutrition: Food-Based Approaches; FAO: Rome, Italy; CAB International: Wallingford, UK; Boston, MA, USA, 2014.

27. Food and Agriculture Organization of the United Nations. The State of Food Insecurity in the World 2014. Strengthering the Enabling Environments for Food Security and Nutrition; FAO: Rome, Italy, 2014; p. 55. 
28. Neumann, C.G.; Bwibo, N.O.; Gewa, C.A.; Drorbaugh, N. Animal source foods as a food-based approach to improve diet and nutrition outcomes. In Improving Diets and Nutrition: Food-Based Approaches; Thompson, B., Amoroso, L., Eds.; CABI: Wallingford, UK, 2014; pp. 157-172.

29. Cassidy, E.S.; West, P.C.; Gerber, J.S.; Foley, J.A. Redefining agricultural yields: From tonnes to people nourished per hectare. Environ. Res. Lett. 2013, 8, http://dx.doi.org/10.1088/174 8-9326/8/3/034015.

30. Smil, V. Feeding the World: A Challenge for the Twenty-First Century; The MIT Press: Cambridge, MA, USA, 2000.

31. D'Mello, J.P.F. Amino Acids in Human Nutrition and Health; Wallingford, UK; Cambridge, MA, USA, 2011; p. 544.

32. Pillai, R.R.; Kurpad, A.V. Amino acid requirements: Quantitative estimates. In Amino Acids in Human Nutrition and Health; D’Mello, J.P.F., Ed.; CABI: Wallingford, UK, 2011; pp. 267-290.

33. Smith, J.; Sones, K.; Grace, D.; MacMillan, S.; Tarawali, S.; Herrero, M. Beyond milk, meat, and eggs: Role of livestock in food and nutrition security. Anim. Front. 2013, 3, 6-13.

34. World Health Organization; Food and Agriculture Organization of the United Nations; United Nations University. Protein and Amino acid Requirements in Human Nutrition; World Health Organization: Geneva, Switzerland, 2007; Volume 935, pp. 1-265.

35. Young, V.R.; Bier, D.M.; Pellett, P.L. A theoretical basis for increasing current estimates of the amino acid requirements in adult man, with experimental support. Am. J. Clin. Nutr. 1989, 50, 80-92.

36. Wennemer, H.; Flachowsky, G.; Hoffmann, V. Protein, Population, Politics-How Protein Can Be Supplied Sustainable in the 21st Century; Plexus Verlag: Mittenberg, Switzerland; Frankfurt, Germany; 2006; p. 160.

37. Jackson, A.A. Protein. In Essentials of Human Nutrition, 3rd ed.; Mann, J., Truswell, S., Eds.; Oxford University Press: Oxford, UK, 2007; pp. 53-72.

38. Waterlow, J.C. The mysteries of nitrogen balance. Nutr. Res. Rev. 1999, 12, 25-54.

39. Bauer, J.; Biolo, G.; Cederholm, T.; Cesari, M.; Cruz-Jentoft, A.J.; Morley, J.E.; Phillips, S.; Sieber, C.; Stehle, P.; Teta, D.; et al. Evidence-based recommendations for optimal dietary protein intake in older people: A position paper from the prot-age study group. J. Am. Med. Dir. Assoc. 2013, 14, 542-559.

40. Fukagawa, N.K. Protein requirements: Methodologic controversy amid a call for change. Am. J. Clin. Nutr. 2014, 99, 761-762.

41. Marini, J.C. Protein requirements: Are we ready for new recommendations? J. Nutr. 2015, 145, 5-6.

42. Rand, W.M.; Pellett, P.L.; Young, V.R. Meta-analysis of nitrogen balance studies for estimating protein requirements in healthy adults. Am. J. Clin. Nutr. 2003, 77, 109-127.

43. Avadi, A.; Freon, P. Life cycle assessment of fisheries: A review for fisheries scientists and managers. Fish. Res. 2013, 143, 21-38.

44. Van Huis, A.; Dicke, M.; van Loon, J.J.A. Insects to feed the world. J. Insects Food Feed 2015, $1,3-5$.

45. Kastner, T.; Rivas, M.J.; Koch, W.; Nonhebel, S. Global changes in diets and the consequences for land requirements for food. Proc. Natl. Acad. Sci. USA 2012, 109, 6868-6872. 
46. Keyzer, M.A.; Merbis, M.D.; Pavel, I.F.P.W.; van Wesenbeeck, C.F.A. Diet shifts towards meat and the effects on cereal use: Can we feed the animals in 2030? Ecol. Econ. 2005, 55, 187-202.

47. Tilman, D.; Balzer, C.; Hill, J.; Befort, B.L. Global food demand and the sustainable intensification of agriculture. Proc. Natl. Acad. Sci. USA 2011, 108, 20260-20264.

48. Guyomard, H.; Manceron, S.; Peyraud, J.L. Trade in feed grains, animals, and animal products: Current trends, future prospects, and main issues. Anim. Front. 2013, 3, 14-18.

49. Flachowsky, G. Carbon footprints for food of animal origin. In Livestock Production and Climate Change; Malik, P.K., Bhatta, R., Takahashi, J., Kohn, R., Prasad, C.S., Eds.; CABI: Wallingford, UK, 2015; pp.125-145.

50. Gerbens-Leenes, P.W.; Nonhebel, S. Consumption patterns and their effects on land required for food. Ecol. Econ. 2002, 42, 185-199.

51. Wirsenius, S.; Azar, C.; Berndes, G. How much land is needed for global food production under scenarios of dietary changes and livestock productivity increases in 2030? Agric. Syst. 2010, 103, 621-638.

52. Food and Agriculture Organization of the United Nations. Dairy Asia: Towards sustainability. In Proceedings of an International Consultation, Bangkok, Thailand, 21-23 May 2014; FAO Regional Office for Asia and the Pacific: Bangkok, Thailand, 2014; p. 65.

53. Kebreab, E. Sustainable Animal Agriculture; CABI: Wallingford, UK, 2013.

54. SAFA. Sustainable Assessment of Food and Agriculture Systems Indicators; FAO: Rome, Italy, 2013.

55. Guyomard, H.; Darcy-Vrillon, B.; Esnouf, C.; Marin, M.; Russel, M.; Guillou, M. Eating patterns and food systems: Critical knowledge requirements for policy design and implementation. Agric. Food Secur. 2012, 1, doi:10.1186/2048-7010-1-13.

56. Baroni, L.; Cenci, L.; Tettamanti, M.; Berati, M. Evaluating the environmental impact of various dietary patterns combined with different food production systems. Eur. J. Clin. Nutr. 2007, 61, 279-286.

57. Pimentel, D.; Pimentel, M. Sustainability of meat-based and plant-based diets and the environment. Am. J. Clin. Nutr. 2003, 78, 660S-663S.

58. Reijnders, L.; Soret, S. Quantification of the environmental impact of different dietary protein choices. Am. J. Clin. Nutr. 2003, 78, 664S-668S.

59. Flachowsky, G.; Meyer, U.; Südekum, K.-H. Land use for edible protein of animal origin-A review. Food Secur. 2015, 6, in press.

60. Peters, C.J.; Wilkins, J.L.; Fick, G.W. Testing a complete-diet model for estimating the land resource requirements of food consumption and agricultural carrying capacity: The New York state example. Renew. Agric. Food Syst. 2007, 22, 145-153.

61. Deikman, J.; Petracek, M.; Heard, J.E. Drought tolerance through biotechnology: Improving translation from the laboratory to farmers' fields. Curr. Opin. Biotechnol. 2012, 23, 243-250.

62. Hoekstra, A.Y.; Chapagain, A.K. Water footprints of nations: Water use by people as a function of their consumption pattern. Water Resour. Manag. 2007, 21, 35-48.

63. Molden, D.; Oweis, T.; Steduto, P.; Bindraban, P.; Hanjra, M.A.; Kijne, J. Improving agricultural water productivity: Between optimism and caution. Agric. Water Manag. 2010, 97, 528-535. 
64. Schlink, A.C.; Nguyen, M.L.; Viljoen, G.J. Water requirements for livestock production: A global perspective. Rev. Sci. Technol. 2010, 29, 603-619.

65. Hall, D.C.; Hall, J.V. Concepts and measures of natural-resource scarcity with a summary of recent trends. J. Environ. Econ. Manag. 1984, 11, 363-379.

66. Scholz, R.W.; Wellmer, F.W. Approaching a dynamic view on the availability of mineral resources: What we may learn from the case of phosphorus? Glob. Environ. Chang. 2013, 23, $11-27$.

67. Aerts, S. Agriculture's 6 F's and the need for more intensive agriculture. In Climate Change and Sustainable Development; Potthast, T., Meisch, S., Eds.; Wageningen Academic Publisher: Wageningen, The Netherlands 2012; pp. 192-195.

68. Amarsinghe, U. Water footprint of the dairy sector. In Proceedings of an International Consultation, Bangkok, Thailand, 21-23 May 2014; FAO Regional Office for Asia and the Pacific: Bangkok, Thailand, 2014; pp. 14-15.

69. Mekonnen, M.M.; Hoekstra, A.V. The Green, Blue and Grey Water Footprint of Farm Animals and Animal Products; UNESCO-IHE: Delft, The Neterlands, 2010.

70. De Vries, M.; de Boer, I.J.M. Comparing environmental impacts for livestock products: A review of life cycle assessments. Livest. Sci. 2010, 128, 1-11.

71. Nguyen, T.L.T.; Hermansen, J.E.; Mogensen, L. Environmental consequences of different beef production systems in the EU. J. Clean. Prod. 2010, 18, 756-766.

72. Nijdam, D.; Rood, T.; Westhoek, H. The price of protein: Review of land use and carbon footprints from life cycle assessments of animal food products and their substitutes. Food Policy 2012, 37, 760-770.

73. Upham, P.; Dendler, L.; Bleda, M. Carbon labelling of grocery products: Public perceptions and potential emissions reductions. J. Clean. Prod. 2011, 19, 348-355.

74. Young, W.; Hwang, K.; McDonald, S.; Oates, C.J. Sustainable consumption: Green consumer behaviour when purchasing products. Sustain. Dev. 2010, 1, 20-31.

75. De Alvarenga, R.A.F.; Silva Junior, V.P.D.; Soares, S.R.; de Alvarenga, R.A.F.; da Silva Junior, V.P. Comparison of the ecological footprint and a life cycle impact assessment method for a case study on brazilian broiler feed production. J. Clean. Prod. 2012, 28, 25-32.

76. Boonen, R.; Aerts, S.; de Tavernier, L. Which sustainability soits you? In Climate Change and Sustainable Development; Potthast, T., Meisch, S., Eds.; Wageningen Academic Publishers: Wageningen, The Netherlands, 2012; pp. 43-48.

77. International Union for Conservation of Nature. The IUNC Programm 2005-2008. IUCN: Gland, Switzerland, 2005.

78. Casabona, C.M.R.; Epifanio, L.E.S.; Cirion, A.E. Global Food Security: Ethical and Legal Callenges; Wageningen Academic Publishers: Wageningen, The Netherlands, 2010; p. 532.

79. Fedoroff, N.V.; Battisti, D.S.; Beachy, R.N.; Cooper, P.J.; Fischhoff, D.A.; Hodges, C.N.; Knauf, V.C.; Lobell, D.; Mazur, B.J.; Molden, D.; et al. Radically rethinking agriculture for the 21 st century. Science 2010, 327, 833-834. 
80. Giovannucci, D.; Scherr, S.; Nierenberg, D.; Hebebrand, C.; Shapiro, J.; Milder, J.; Wheeler, K. Food and Agriculture: The Future of Sustainability. A Strategic Input to the Sustainable Development in the 21st Century (SD21) Project; United Nations Department of Economic and Social Affairs: New York, NY, USA, 2012.

81. Wals, A.E.J.; Corcoran, P.B. Learning for Sustainability in Times of Accelerating Change; Wageningen Academic Publishers: Wageningen, The Netherlands, 2012; p. 550.

82. Foley, J.A.; Ramankutty, N.; Brauman, K.A.; Cassidy, E.S.; Gerber, J.S.; Johnston, M.; Mueller, N.D.; O'Connell, C.; Ray, D.K.; West, P.C.; et al. Solutions for a cultivated planet. Nature 2011, 478, 337-342.

83. Girard, C.L. Insects as a source of nutrients: Beyond the western prejudices. Anim. Front. 2015, $5,4-6$.

84. Morales-Ramos, J.A.; Rojas, M.G.; Shapiro-Ilan, D. Mass Production of Beneficial Organisms-Invertebrates and Entomopathogens; Elsevier and Academic Press: Amsterdam, The Netherlands, 2014; p. 712.

85. Rumpold, B.A.; Schlüter, O. Insect-based protein sources and their potential for human consumption: Nutritional composition and processing. Anim. Front. 2015, 5, 20-24.

86. Sanchez-Muros, M.J.; Barroso, F.G.; Manzano-Agugliaro, F. Insect meal as renewable source of food for animal feeding: A review. J. Clean. Prod. 2014, 65, 16-27.

87. Van Huis, A.; Itterbeeck, J.V.; Klunder, H.; Mertens, E.; Halloran, A.; Muir, G.; Vantomme, P.; van Huis, A.; van Itterbeeck, J. Edible Insects: Future Prospects for Food and Feed Security; FAO: Rome, Italy, 2013.

88. Anupama, R.P. Value-added food: Single cell protein. Biotechnol. Adv. 2000, 18, 459-479.

89. Zepka, L.Q.; Jacob-Lopes, E.; Goldbeck, R.; Souza-Soares, L.A.; Queiroz, M.I. Nutritional evaluation of single-cell protein produced by aphanothece microscopica nageli. Bioresour. Technol. 2010, $101,7118-7122$.

90. Flachowsky, G. Greenhouse gases and resource efficiency. Aspects of production of food of animal origin. Ernähr.-Umsch. 2008, 55, 414-419. (In German)

91. Makkar, H.P.S. Biofuel Co-Products as Livestock Feed-Opportunities and Challenges; FAO: Rome, Italy, 2012.

92. Becker, M.; Nehring, K. Handbook of Feeds; Paul Parey Verlag: Hamburg, Germany; 1967; pp. 1-3. (In German)

93. Menke, K.H.; Huss, W. Animal Nutrition and Feedstuffs: Tierernährung und Futtermittelkunde; Verlag Eugen Ulmer: Stuttgart, Germany, 1975; p. 319. (In German)

94. Kling, M.; Woehlbier, W. Trade Feestuffs; Ulmer Verlag: Stuttgart, Germany, 1983; p. 546. (In German)

95. Jeroch, H.; Flachowsky, G.; Weissbach, F. Futtermittelkunde; Gustav Fischer Verlag Jena: Stuttgart, Germany, 1993; p. 510.

96. Jeroch, H.; Simon, A.; Zentek, J. Poultry Nutrition; Verlag Eugen Ulmer: Stuttgart, Germany, 2013; p. 528. (In German)

97. Jeroch, H.; Simon, O.; Drochner, W. Nutrition of Livestock, 2nd ed.; Eugen-Ulmer Verlag: Stuttgart, Germany, 2008; p. 555. (In German) 
98. Theodorou, M.K.; France, J. Feeding Systems and Feed Evaluation Models; CABI: Wallingford, UK, 2000; p. 481.

99. Ewing, W.N. The FEEDS Directory: Commody Products Guide; Context Products Ltd.: Packington, UK, 1998; p. 234.

100. Ewing, W.N. The Feeds Directory: Branded Products Guide; Context Products Ltd.: Packington, UK, 2002; p. 216.

101. Kamphues, J.; Wolf, P.; Coenen, M.; Eder, K.; Iben, C.; Kienzle, E.; Liesegang, A.; Maenner, K.; Zebeli, Q.; Zentek, J. Supplements of Animal Nutrition for Study and Practice; M. \& H. Schaper GmbH: Hannover, Germany, 2014; p. 520. (In German)

102. Positive, L. Positive List for Straight Feeding Stuffs; Standards Commission for Straight Feeding Stuffs at the Central Committee of the German Agriculture: Bonn, Germany, 2014; p. 61.

103. Pape, H.-C. Feed Additives-Technology and Application; Agrimedia GmbH: Bergen, Norway, 2006; p. 304. (In German)

104. Salem, A.-F.Z.M. Plant-Phytochemicals in Animal Nutrition; Nova Science Publishers Inc.: Hauppauge, New York, NY, USA, 2011; p. 188.

105. Salem, A.-F.Z.M. Nutritional Strategies of Animal Feed Additives; Nova Sciene Publishers Inc.: Hauppauge, New York, NY, USA, 2012; p. 221.

106. Pennisi, E. Sowing the seeds for the ideal crop. Science 2010, 327, 802-803.

107. SCAR. New Challenges for Agricultural Research: Climate Change, Rural Development, Agricultural Knowledge Systems; European Communities: Brussels, Belgium, 2008; p. 112.

108. Flachowsky, G. Global Food Security: Is There Any Solution?. NovoArgument 2010, 105, 3-4. (In German)

109. High Level Panel of Experts. Food Security and Climate Change; FAO: Rome, Italy, 2012; p. 98.

110. Husaini, A.M.; Tuteja, N. Biotech crops: Imperative for achieving the millenium development goals and sustainability of agriculture in the climate change era. GM Crop. Food 2013, 4, 1-9.

111. Lobell, D.B.; Burke, M.B.; Tebaldi, C.; Mastrandrea, M.D.; Falcon, W.P.; Naylor, R.L. Prioritizing climate change adaptation needs for food security in 2030. Science 2008, 319, 607-610.

112. Newman, J.A.; Anand, M.; Henry, H.A.L.; Hunt, S.; Gedalof, Z. Climate Change Biology; CABI: Wallingford, UK, 2011.

113. Tillie , P.; Dillen, K.; Rodriguez-Cerezo, E. The pipeline of gm crops for improved animal feed: Challenges for commercial use. In Animal Nutrition with Transgenic Plants; Flachowsky, G., Ed.; CABI: Wallingford, UK, 2013; pp. 166-192.

114. Bouis, H.E.; Chassy, B.A.; Ochanda, J.O. Genetically modified food crops and their contribution to human nutrition and food quality. Trends Food Sci. Technol. 2003, 14, 191-209.

115. Hirschi, K.D. Nutrient biofortification of food crops. Annu. Rev. Nutr. 2009, 29, 401-421.

116. Welch, R.M. Breeding strategies for biofortified staple plant foods to reduce micronutrient malnutrition globally. J. Nutr. 2002, 132, 495S-499S.

117. White, P.J.; Broadley, M.R. Biofortifying crops with essential mineral elements. Trends Plant Sci. 2005, 10, 586-593.

118. Nestel, P.; Bouis, H.E.; Meenakshi, J.V.; Pfeiffer, W. Biofortification of staple food crops. J. Nutr. 2006, 136, 1064-1067. 
119. McDowell, L.R. Minerals in Animal and Human Nutrition; Elsevier: Amsterdam, The Netherlands, 2003.

120. Suttle, N. Mineral Nutrition of Livestock; CABI: Wallingford, UK, 2010.

121. Lucas, D.M.; Taylor, M.L.; Hartnell, G.F.; Nemeth, M.A.; Glenn, K.C.; Davis, S.W. Broiler performance and carcass characteristics when fed diets containing lysine maize (LY038 or LY038 × MON 810), control, or conventional reference maize. Poultr. Sci. 2007, 86, 2152-2161.

122. Sevenier, R.; van der Meer, I.M.; Bino, R.; Koops, A.J. Increased production of nutriments by genetically engineered crops. J. Am. Coll. Nutr. 2002, 21, 199S-204S.

123. Ufaz, S.; Galili, G. Improving the content of essential amino acids in crop plants: Goals and opportunities. Plant Physiol. 2008, 147, 954-961.

124. Cahoon, E.B.; Shockey, J.M.; Dietrich, C.R.; Gidda, S.K.; Mullen, R.T.; Dyer, J.M. Engineering oilseeds for sustainable production of industrial and nutritional feedstocks: Solving bottlenecks in fatty acid flux. Curr. Opin. Plant Biol. 2007, 10, 236-244.

125. Napier, J.A. The production of unusual fatty acids in transgenic plants. Annu. Rev. Plant Biol. 2007, 58, 295-319.

126. Rymer, C.; Hartnell, G.F.; Givens, D.I. The effect of feeding modified soyabean oil enriched with C18: $4 n-3$ to broilers on the deposition of $n-3$ fatty acids in chicken meat. Br. J. Nutr. 2011, $105,866-878$.

127. Broadley, M.R.; White, P.J.; Bryson, R.J.; Meacham, M.C.; Bowen, H.C.; Johnson, S.E.; Hawkesford, M.J.; McGrath, S.P.; Zhao, F.J.; Breward, N.; et al. Biofortification of UK food crops with selenium. Proc. Nutr. Soc. 2006, 65, 169-181.

128. Gregorio, G.B. Progress in breeding for trace minerals in staple crops. J. Nutr. 2002, 132, 500S-502S.

129. Lucca, P.; Hurrell, R.; Potrykus, I. Genetic engineering approaches to improve the bioavailability and the level of iron in rice grains. Theor. Appl. Genet. 2001, 102, 392-397.

130. Welch, R.M.; Graham, R.D. Breeding for micronutrients in staple food crops from a human nutrition perspective. J. Exp. Bot. 2004, 55, 353-364.

131. Welch, R.M.; House, W.A.; Beebe, A.; Senadhira, D.; Gregorio, G.B.; Cheng, Z. Testing iron and zinc bioavailability in genetically enriched beans (Phaseolus vulgaris L.) and rice (Oryza sativa L.) in a rat model. Food Nutr. Bull. 2000, 21, 428-433.

132. Garza, R.D.D.L.; Quinlivan, E.P.; Klaus, S.M.J.; Basset, G.J.C.; Gregory, J.F., III; Hanson, A.D.; de la Garza, R.D. Folate biofortification in tomatoes by engineering the pteridine branch of folate synthesis. Proc. Natl. Acad. Sci. USA 2004, 101, 13720-13725.

133. Potrykus, I. Golden rice and beyond. Plant Physiol. 2001, 125, 1157-1161.

134. Rocheford, T.R.; Wong, J.C.; Egesel, C.O.; Lambert, R.J. Enhancement of vitamin E levels in corn. J. Am. Coll. Nutr. 2002, 21, 191S-198S.

135. Van Jaarsveld, P.J.; Faber, M.; Tanumihardjo, S.A.; Nestel, P.; Lombard, C.J.; Benade, A.J. Beta-carotene-rich orange-fleshed sweet potato improves the vitamin a status of primary school children assessed with the modified-relative-dose-response test. Am. J. Clin. Nutr. 2005, 81, 1080-1087. 
136. Ye, X.; Al-Babili, S.; Kloti, A.; Zhang, J.; Lucca, P.; Beyer, P.; Potrykus, I. Engineering the provitamin a ( $\beta$-carotene) biosynthetic pathway into (carotenoid-free) rice endosperm. Science 2000, 287, 303-305.

137. Chen, R.; Xue, G.; Chen, P.; Yao, B.; Yang, W.; Ma, Q.; Fan, Y.; Zhao, Z.; Tarczynski, M.C.; Shi, J. Transgenic maize plants expressing a fungal phytase gene. Transgen. Res. 2008, 17, 633-643.

138. Gao, C.Q.; Ma, Q.G.; Ji, C.; Luo, X.G.; Tang, H.F.; Wei, Y.M. Evaluation of the compositional and nutritional values of phytase transgenic corn to conventional corn in roosters. Poultr. Sci. 2012, 91, 1142-1148.

139. Nyannor, E.K.; Williams, P.; Bedford, M.R.; Adeola, O. Corn expressing an Escherichia coli-derived phytase gene: A proof-of-concept nutritional study in pigs. J. Anim. Sci. 2007, 85, 1946-1952.

140. Zhang, Z.B.; Kornegay, E.T.; Radcliffe, J.S.; Denbow, D.M.; Veit, H.P.; Larsen, C.T. Comparison of genetically engineered microbial and plant phytase for young broilers. Poultr. Sci. 2000, 79, 709-717.

141. Vageeshbabu, H.S.; Chopra, V.L. Genetic and biotechnological approaches for reducing glucosinolates from rapeseed-mustard meal. J. Plant Biochem. Biotechnol. 1997, 6, 53-62.

142. Vasil, I.K.; Anderson, O.D. Genetic engineering of wheat gluten. Trends Plant Sci. 1997, 2, 292-297.

143. Duvick, J. Prospects for reducing fumonisin contamination of maize through genetic modification. Environ. Health Perspect. 2001, 109, 337-342.

144. Munkvold, G.P.; Hellmich, R.L.; Rice, L.G. Comparison of fumonisin concentrations in kernels of transgenic Bt maize hybrids and nontransgenic hybrids. Plant Dis. 1999, 83, 130-138.

145. International Life Sciences Institute. Nutritional and safety of foods and feeds nutritionally improved through biotechnology: Case studies. Compr. Rev. Food Sci. Food Saf. 2008, 7, 50-99.

146. Newell-McGloughlin, M. Nutritionally improved agricultural crops. Plant Physiol. 2008, 147, 939-953.

147. Dawe, D.; Robertson, R.; Unnevehr, L. Golden rice: What role could it play in alleviation of vitamin a deficiency? Food Policy 2002, 27, 541-560.

148. DellaPenna, D. Nutritional genomics: Manipulating plant micronutrients to improve human health. Science 1999, 285, 375-379.

149. Gilligan, D.O. Biofortification, agricultural technology adoption, and nutrition policy: Some lessons and emerging challenges. CESifo Econo. Stud. 2012, 58, 405-421.

150. Johns, T. Plant biodiversity and malnutrition: Simple solutions to complex problems. Afr. J. Food Agric. Nutr. Dev. 2003, 3, 45-52.

151. King, J.C. Evaluating the impact of plant biofortification on human nutrition. J. Nutr. 2002, 132, 511S-513S.

152. Mayer, J.E.; Pfeiffer, W.H.; Beyer, P. Biofortified crops to alleviate micronutrient malnutrition. Curr. Opin. Plant Biol. 2008, 11, 166-170.

153. McKeon, T.A. Genetically modified crops for industrial products and processes and their effects on human health. Trends Food Sci. Technol. 2003, 14, 229-241.

154. Sautter, C.; Poletti, S.; Zhang, P.; Gruissem, W. Biofortification of essential nutritional compounds and trace elements in rice and cassava. Proc. Nutr. Soc. 2006, 65, 153-159. 
155. Zimmermann, R.; Stein, A.; Qaim, M. Agricultural technology to fight micronutrient malnutrition? A health economics approach agrartechnologie zur bekampfung von mikronahrstoffmangel? Ein gesundheitsokonomischer bewertungsansatz. Agrarwirtschaft 2004, 53, 67-76.

156. McNaughton, J.; Roberts, M.; Smith, B.; Rice, D.; Hinds, M.; Sanders, C.; Layton, R.; Lamb, I.; Delaney, B. Comparison of broiler performance when fed diets containing event DP-3O5423-1, nontransgenic near-isoline control, or commercial reference soybean meal, hulls, and oil. Poultr. Sci. 2008, 87, 2549-2561.

157. Mejia, L.; Meyer, E.T.; Utterback, P.L.; Utterback, C.W.; Parsons, C.M.; Koelkebeck, K.W. Evaluation of limit feeding corn and distillers dried grains with solubles in non-feed-withdrawal molt programs for laying hens. Poultr. Sci. 2010, 89, 386-392.

158. Stein, A.J.; Rodriguez-Cerezo, E. The Global Pipeline of New GM-Crops: Implications of Asynchronous Approval for International Trade; European Communities: Brussels, Belgium, 2009; p. 102.

159. Flachowsky, G. Possibilities of decontamination of "undesired substances" after appendix 5 of the feed regulation. Landbauforsch. Völk. 2006, 294, 292. (In German)

160. Gorniak, T.; Meyer, U.; Danicke, S. Effects of corn silage of a brown-midrib hybrid on dry matter intake, milk yield and milk composition in german holstein dairy cows compared to a common hybrid. Proc. Soc. Nutr. Physiol. Band 2012, 21, 159.

161. Ivan, S.K.; Grant, R.J.; Weakley, D.; Beck, J. Comparison of a corn silage hybrid with high cell-wall content and digestibility with a hybrid of lower cell-wall content on performance of holstein cows. J. Dairy Sci. 2005, 88, 244-254.

162. Köhler, R.; Leuoth, A.; Jeroch, H.; Flachowsky, G.; Gebhardt, G.; Hielscher, H.; Kappel, W. Studies of the content and the digestibility of cell-wall substances in remaining plants of various maize hybrids. Arch. Anim. Nutr. 1989, 39, 187-192.

163. Rook, J.A.; Muller, L.D.; Shank, D.B. Intake and digestibility of brown-midrib corn-silage by lactating dairy-cows. J. Dairy Sci. 1977, 60, 1894-1904.

164. Barriere, Y.; Dias Goncalves, G.; Emile, J.C.; Lefevre, B. Higher intake of DK265 corn silage by dairy cattle. J. Dairy Sci. 2004, 87, 1439-1445.

165. Oba, M.; Allen, M.S. Effects of brown midrib 3 mutation in corn silage on dry matter intake and productivity of high yielding dairy cows. J. Dairy Sci. 1999, 82, 135-142.

166. Oba, M.; Allen, M.S. Effects of brown midrib 3 mutation in corn silage on productivity of dairy cows fed two concentrations of dietary neutral detergent fiber: 1 . Feeding behavior and nutrient utilization. J. Dairy Sci. 2000, 83, 1333-1341.

167. Oba, M.; Allen, M.S. Effects of brown midrib 3 mutation in corn silage on productivity of dairy cows fed two concentrations of dietary neutral detergent fiber: 3 . Digestibility and microbial efficiency. J. Dairy Sci. 2000, 83, 1350-1358.

168. Cherney, J.H.; Cherney, D.J.R.; Akin, D.E.; Axtell, J.D. Potential of brown-midrib, low-lignin mutants for improving forage quality. Adv. Agron. 1991, 46, 157-198.

169. Grant, R.J.; Haddad, S.G.; Moore, K.J.; Pedersen, J.F. Brown midrib sorghum silage for midlactation dairy cows. J. Dairy Sci. 1995, 78, 1970-1980.

170. Taylor, C.C.; Allen, M.S. Corn grain endosperm type and brown midrib 3 corn silage: Ruminal fermentation and n partitioning in lactating cows. J. Dairy Sci. 2005, 88, 1434-1442. 
171. Taylor, C.C.; Allen, M.S. Corn grain endosperm type and brown midrib 3 corn silage: Feeding behavior and milk yield of lactating cows. J. Dairy Sci. 2005, 88, 1425-1433.

172. Hristov, A.N.; Oh, J.; Firkins, J.L.; Dijkstra, J.; Kebreab, E.; Waghorn, G.; Makkar, H.P.S.; Adesogan, A.T.; Yang, W.; Lee, C.; et al. Mitigation of methane and nitrous oxide emissions from animal operations: I. A review of enteric methane mitigation options. J. Anim. Sci. 2013, 91, 5045-5069.

173. Schwarm, A.; Schweigel-Röntgen, M.; Kreuzer, M.; Ortmann, S.; Gill, F.; Kuhla, B.; Meyer, U.; Lohölter, M.; Derno, M. Feeding silage from brown midrib maize to heifers does not increase methane emissions despite a higher fibre digestibilitgy as compared to conventional maize silage. Arch. Anim. Nutr. 2015, 69, 159-176.

174. Flachowsky, G. Stroh als Futtermittel: Ergebnisse und Erfahrungen bei der Strohaufbereitung und Beim Einsatz von Unterschiedlich Behandeltem Stroh als Futtermittel; VEB Deutscher Landwirtschaftsverlag: Berlin, Germany, 1987. (In German)

175. Sundstol, F.; Owen, E. Straw and Other Fibrous by Products as Feed; Elsevier: Amsterdam, The Netherlands, 1984; p. 610.

176. Van Soest, P.J. Nutritional Ecology of the Ruminant, 2nd ed.; Cornell University Press: Ithaca, NY, USA, 1994; p. 376.

177. Van Soest, P.J. Rice straw, the role of silica and treatments to improve quality. Anim. Feed Sci. Technol. 2006, 130, 137-171.

178. Protocols for Food and Feed Safety Assessment of Ge Crops; Available online: http://igmoris.nic.in/files\%5CCoverpage1.pdf (accessed on 12 May 2015).

179. EFSA GMO Panel Working Group on Animal Feeding Trials. Safety and nutritional assessment of GM plant derived food and feed. The role of animal feeding trials. Food Chem. Toxicol. 2008, 46, 2-70.

180. The Role of Animal Feeding Studies in the Safety Assessment of Genetically Modified Foods; Available online: https://www.foodstandards.gov.au/consumer/gmfood/documents/Workshop \%20Report\%20FINAL.pdf (accessed on 12 May 2015).

181. International Life Sciences Institute. Best Practices for the Conduct of Animal Studies to Evaluate Crops Genetically Modified for Input Traits; International Life Sciences Institute: Washington, DC, USA, 2003; p. 62.

182. International Life Sciences Institute. Best Practices for the Conduct of Animal Studies to Evaluate Crops Genetically Modified for Output Traits; International Life Sciences Institute: Washington, DC, USA, 2007; p. 194.

183. Organization for Economic Co-operation and Development. Safety Evaluation of Foods Derived by Modern Biotechnology: Concepts and Principles; OECD: Paris, France, 1993; p. 77.

184. Van Eenennaam, A.L.; Young, A.E. Prevalence and impacts of genetically engineered feedstuffs on livestock populations. J. Anim. Sci. 2014, 92, 4255-4278.

185. Flachowsky, G.; Böhme, H. Proposals for nutritional assessments of feeds from genetically modified plants. J. Anim. Feed Sci. 2005, 14, 49-70.

186. Flachowsky, G.; Schafft, H.; Meyer, U. Animal feeding studies for nutritional and safety assessments of feeds from genetically modified plants: A review. J. Verbrauch. Lebensm. 2012, 7, 179-194. 
187. Llorente, B.; Alonso, G.D.; Bravo-Almonacid, F.; Rodriguez, V.; Lopez, M.G.; Carrari, F.; Torres, H.N.; Flawia, M.M. Safety assessment of nonbrowning potatoes: Opening the discussion about the relevance of substantial equivalence on next generation biotech crops. Plant Biotechnol. J. 2011, 9, 136-150.

188. Spencer, J.D.; Allee, G.L.; Sauber, T.E. Phosphorus bioavailability and digestibility of normal and genetically modified low-phytate corn for pigs. J. Anim. Sci. 2000, 78, 675-681.

189. Spencer, J.D.; Allee, G.L.; Sauber, T.E. Growing-finishing performance and carcass characteristics of pigs fed normal and genetically modified low-phytate corn. J. Anim. Sci. 2000, 78, 1529-1536.

(C) 2015 by the authors; licensee MDPI, Basel, Switzerland. This article is an open access article distributed under the terms and conditions of the Creative Commons Attribution license (http://creativecommons.org/licenses/by/4.0/). 